\title{
Alternative Carbon Assimilation Pathways in Methane-utilizing Bacteria
}

\author{
By A. J. LAWRENCE AND J. R. QUAYLE \\ Department of Microbiology, University of Sheffield, Sheffield, SIo 2 TN
}

(Accepted for publication 31 August 1970)

An examination of three species of methane-utilizing bacteria has shown (Lawrence, Kemp \& Quayle, 1970) that the bacteria use one of two pathways of carbon assimilation, the serine pathway (Heptinstall \& Quayle, I970) or the ribose phosphate cycle of formaldehyde fixation (Kemp \& Quayle, 1967). The isolation of many new types of methane-utilizing bacteria by Whittenbury, Phillips \& Wilkinson (1970) has made possible an extension of these studies, and this paper reports the results of an examination of eight of the new isolates. The examination is based on the distribution of two key enzymes, each of which appears to be specifically involved in one of the assimilation pathways, namely hydroxypyruvate reductase (serine pathway) and hexose phosphate synthetase (ribose phosphate cycle).

\section{METHODS}

Growth of the organisms. The following organisms were kindly provided by $\mathrm{Dr}$ R. Whittenbury, Department of General Microbiology, University of Edinburgh (the symbols in parentheses denote the particular strain): 'Methylosinus sporium' (5), 'Methylosinus trichosporium' (ОВ 3 b), 'Methylocystis parvus' (ОВ ВР), 'Methylomonas agile' (Y I), 'Methylomonas rosaceus' (BG 2), 'Methylomonas methanica' (25), 'Methylococcus minimus' (TMC) and 'Methylobacter capsulatus' (I52I). The bacteria were grown in liquid salts medium (Foster \& Davis, 1966) under an atmosphere of methane-air ( $\mathrm{I}: \mathrm{I})$ in conical flasks shaken at $30^{\circ}$. 'Methylobacter capsulatus' would grow in liquid medium only if the starter culture was supplemented with an aqueous extract of agar. The extract was prepared from Difco agar by the method of Dworkin \& Foster (1956) and $0.5 \mathrm{ml}$. (containing $22.5 \mathrm{mg}$. dry wt) was added to $10 \mathrm{ml}$. of the starter culture. Pseudomonas methanica (Dworkin \& Foster, 1956), Methylococcus capsulatus (Foster \& Davis, 1966) and Methanomonas methanooxidans (Stocks \& McCleskey, 1964) were grown up in a fermentor on methane as carbon source using the growth technique described by Lawrence et al. (I970). The bacterial paste harvested from the fermentor was freeze-dried and stored at $-15^{\circ}$ until used.

Preparation of bacteria-free extracts. Bacteria, I g. (wet wt) or $0 . \mathrm{I}$ g. (dry wt), were suspended in $5 \mathrm{ml}$. of $20 \mathrm{~mm}$-sodium phosphate buffer, $\mathrm{pH} 7 \cdot 0$, supplemented with 5 mM-magnesium chloride, sonicated until maximum breakage had occurred $(<8 \mathrm{~min}$.) in an MSE sonicator (type $100 \mathrm{~W}$ ) and the resulting suspensions centrifuged at $90,000 \mathrm{~g}$ for $30 \mathrm{~min}$. The supernatant fraction was poured off and the pellet resuspended in $5 \mathrm{ml}$. of the same buffer used to suspend the bacteria. 
Enzyme assays. The activities of hexose phosphate synthetase and hydroxypyruvate reductase in the supernatant and pellet fractions were measured by the procedures of Lawrence et al. (1970). The specific activity of hydroxypyruvate reductase is expressed as $\mu$ moles of NADH oxidized/h./mg. protein. The specific activity of hexose phosphate synthetase is expressed as $\mu$ moles of $\left[{ }^{14} \mathrm{C}\right]$ formaldehyde fixed $/ \mathrm{h} . / \mathrm{mg}$. protein. In the assays for hexose phosphate synthetase, control assays were performed by incubating $\left[{ }^{14} \mathrm{C}\right]$ formaldehyde with extract in the absence of ribose 5-phosphate. The control values were subtracted from the test values obtained with ribose 5-phosphate present in the assay mixture.

Protein determinations. Protein was determined by the method of Folin and Ciocalteu as described by Layne (1957), with bovine serum albumin as standard.

\section{RESULTS AND DISCUSSION}

The enzyme distribution in the eight new isolates and in Pseudomonas methanica (Dworkin \& Foster), Methylococcus capsulatus (Foster \& Davis) and Methanomonas methanooxidans (Stocks \& McCleskey) is shown in Table I. It can be seen that the clear division of organisms into those which contain hydroxypyruvate reductase and those which contain hexose phosphate synthetase, initially seen in the case of the

Table I. Specific activities of hydroxypyruvate reductase and hexose phosphate synthetase in extracts of methane-grown bacteria

\begin{tabular}{|c|c|c|c|c|c|}
\hline \multirow[b]{2}{*}{ Organism } & \multirow{2}{*}{$\begin{array}{l}\text { Test of } \\
\text { membrane } \\
\text { system }\end{array}$} & \multicolumn{2}{|c|}{$\begin{array}{c}\text { Hydroxypyruvate } \\
\text { reductase activity } \\
(\mu \text { moles } / \text { mg. protein } / \mathrm{h} .)\end{array}$} & \multicolumn{2}{|c|}{$\begin{array}{l}\text { Hexose phosphate } \\
\text { synthetase activity } \\
(\mu \mathrm{moles} \text { HCHO fixed } / \\
\text { mg. protein } / \mathrm{h} .)\end{array}$} \\
\hline & & Supernatant & Pellet & Supernatant & Pellet \\
\hline es sporium' (5) & II & 80 & n.d. & n.d. & n.d. \\
\hline us trichosporium' (Ов 3 b) & II & $46 \cdot 3$ & n.d. & n.d. & n.d. \\
\hline stis parvus' (ОВ ВP) & II & $9 \mathrm{I}$ & n.d. & n.d. & n.d. \\
\hline $\begin{array}{l}\text { nas methanooxidans } \\
\text { ( McCleskey) }\end{array}$ & II & $72 \cdot 3$ & n.d. & I'I I & $0.54^{*}$ \\
\hline nas agile' (Y I) & 1 & n.d. & n.d. & $18 \cdot 7$ & $8 \cdot 70$ \\
\hline nas rosaceus' (BG 2$)$ & I & n.d. & n.d. & $108 \cdot 8$ & $15 \cdot 5$ \\
\hline nas methanica' (25) & $\mathrm{I}$ & n.d. & n.d. & $78 \cdot 1$ & $3 I \cdot 4$ \\
\hline ter capsulatus' (1521) & I & n.d. & n.d. & $35 \cdot 7$ & $18 \cdot 2$ \\
\hline cus minimus' (TMC) & $\bar{I}$ & n.d. & n.d. & $132 \cdot 2$ & $17 \cdot 8$ \\
\hline $\begin{array}{l}\text { as methanica } \\
\mathrm{n} \& \text { Foster) }\end{array}$ & I & 0.62 & n.d. & $54 \cdot 8$ & $10 \cdot 6^{*}$ \\
\hline cus capsulatus (Foster & $\mathbf{I}$ & n.d. & n.d. & I $8 \cdot 2$ & $22 \cdot 5 *$ \\
\hline
\end{tabular}

n.d. = None detectable.

'Methylosinus sporium' (5)

'Methylosinus trichosporium' (ов 3 b)

'Methylocystis parvus' (ОВ ВР)

Methanomonas methanooxidans

(Stocks \& McCleskey)

'Methylomonas agile' (Y I)

'Methylomonas rosaceus' (BG 2)

'Methylomonas methanica' (25)

'Methylobacter capsulatus' (1521)

'Methylococcus minimus' (TMC)

Pseudomonas methanica

(Dworkin \& Foster)

Methylococcus capsulatus (Foster \& Davis)

* The pellet fraction was washed thrice with $20 \mathrm{mM}$-phosphate buffer, $\mathrm{pH} 7 \cdot 0,+5 \mathrm{~mm}-\mathrm{MgCl}_{2}$ before assay.

last-named three organisms by Lawrence et al. (1970), precisely holds over the wider range that have now been tested. Whittenbury et al. (1970) have tentatively classified the methane-utilizers on the basis of morphology, fine structure and type of resting stage into two vibrioid groups, 'Methylosinus' and 'Methylocystis', and three rod/ coccoid groups, 'Methylomonas', 'Methylobacter' and 'Methylococcus'. On this new 
classification, Mtn. methanooxidans (Stocks \& McCleskey) appears to be a strain of 'Methylosinus' (R. Whittenbury, personal communication), Ps. methanica (Dworkin \& Foster) is a strain of 'Methylomonas methanica', and Mtc. capsulatus (Foster \& Davis) remains similarly named. The II organisms in Table I which have now been screened, although they only constitute a small sample of the total number of strains isolated, are nevertheless representative of each of the different groups proposed by Whittenbury et al. (1970). It thus seems likely that the dichotomy of assimilation pathway observed in this sample of organisms will be a general property amongst methane-utilizing bacteria.

All the methane-utilizing bacteria which have been examined so far possess complex internal membrane systems (Proctor, Norris \& Ribbons, I969; Whittenbury, 1969; Davies \& Whittenbury, 1970; Whittenbury et al. 1970) which have been divided into two basic arrangements (Davies \& Whittenbury, 1970): a series of bundles of disc-shaped vesicles distributed throughout the organism (type I) and a system of paired membranes running throughout the organism or aggregated at the periphery (type II).

It is most interesting to note that the subdivision of the organisms into two classes based on assimilation pathway corresponds exactly with their subdivision based on membrane system. Thus an organism using the serine pathway $\mathrm{f}$ issesses a type II membrane system, whereas an organism using the ribose phosph: e cycle possesses a type I membrane system. It therefore appears likely that the methane-utilizing bacteria, far from being a closely similar group of organisms as might be anticipated from their striking nutritional similarity of being able to grow only on methane or methanol, may in fact be divided into at least two major groups possessing fundamental differences in their mode of carbon assimilation and system of internal membranes. These differences are wide enough to suggest that the two groups of organisms may have evolved quite separately as methane utilizers. If this were so, it raises the question as to why both groups have convergently evolved as obligate methylotrophs.

We acknowledge generous financial support from the Agricultural Division, Imperial Chemical Industries Ltd, Billingham, Co. Durham, and the Science Research Council for a Studentship held by A. J. L.

\section{REFERENCES}

Davies, S. L. \& Whittenbury, R. (1970). Fine structure of methane-utilizing bacteria. Journal of General Microbiology 6r, 227-232.

DWorkin, M. \& Foster, J. W. (1956). Studies on Pseudomonas methanica (Söhngen) nov. comb. Journal of Bacteriology 72, 646-659.

Foster, J. W. \& Davis, R. H. (I966). A methane-dependent coccus, with notes on classification and nomenclature of obligate, methane-utilizing bacteria. Journal of Bacteriology 9r, I924I931.

Heptinstall, J. \& Quayle, J. R. (I970). Pathways leading to and from serine during growth of Pseudomonas AM I on $\mathrm{C}_{1}$ compounds or succinate. Biochemical Journal II7, 563-572.

Kemp, M. B. \& QuAYLE, J. R. (1967). Uptake of $\left[{ }^{14} \mathrm{C}\right]$ formaldehyde and $\left[{ }^{14} \mathrm{C}\right]$ formate by methanegrown Pseudomonas methanica and determination of the hexose labelling pattern after brief incubation with $\left[{ }^{14} \mathrm{C}\right]$ methanol. Biochemical Journal 102, 94-I02.

Lawrence, A. J., KEMP, M. B. \& Quayle, J. R. (1970). Synthesis of cell constituents by methanegrown Methylococcus capsulatus and Methanomonas methanooxidans. Biochemical Journal Ir6, $63 \mathrm{I}-639$. 
LAYNE, E. (1957). In Methods in Enzymology, vol. 3, p. 447. Edited by S. P. Colowick \& N. O. Kaplan. New York: Academic Press.

Proctor, H. M., NorRis, J. R. \& RibBons, D. W. (1969). Fine structure of methane-utilizing bacteria. Journal of Applied Bacteriology 32, I I 8-121.

Stocks, P. K. \& MCCleskey, C. S. (1964). Morphology and physiology of Methanomonas methanooxidans. Journal of Bacteriology 88, 1071-1077.

Whirtenbury, R. (1969). Microbial utilization of methane. Process Biochemistry 4, 5I-56.

Whittenbury, R., Phillips, K. C. \& Wilkinson, J. F. (1970). Enrichment, isolation and some properties of methane-utilizing bacteria. Journal of General Microbiology 6r, 205-218. 